\title{
A New Chemical-Mechanical Polishing Method Based On Colloids Silica and MgO Was Developed For Polishing Y3AI5012 Material
}

\section{Le Anh Duc ( $\square$ leanhducsp@yahoo.com )}

Hanoi University of Industry https://orcid.org/0000-0003-3985-9501

\section{Pham Minh Hieu}

Hanoi University of Industry

Nguyen Minh Quang

Hanoi University of Industry

\section{Research Article}

Keywords: Chemical-mechanical slurry, Yttrium aluminum oxide (Y3Al5012), lonic surface reaction, Montmorillonites, Surface roughness, Polishing

Posted Date: January 3rd, 2022

DOI: https://doi.org/10.21203/rs.3.rs-1198259/v1

License: (c) (i) This work is licensed under a Creative Commons Attribution 4.0 International License. Read Full License 


\section{Abstract}

The material yttrium aluminum oxide $\left(\mathrm{Y}_{3} \mathrm{Al}_{5} \mathrm{O}_{12}\right)$ is one of the materials commonly used in laser devices. For application in optical devices, it is necessary to produce ultra-precise surface quality, however, $\mathrm{Y}_{3} \mathrm{Al}_{5} \mathrm{O}_{12}$ material belongs to the group of difficult-to-machine materials with high brittleness and hardness. Therefore, it is very difficult to ensure that the main criterion when finishing this material to produce a quality surface in the nanometer form with the ability to remove the material is very difficult. To solve this problem, this work provided a new chemical - mechanical polishing mixture. The proposed polishing mixture of $\mathrm{ZrO}_{2}, \mathrm{Na}_{2} \mathrm{SiO}_{3}-5 \mathrm{H}_{2} \mathrm{O}$, and $\mathrm{MgO}$ abrasives has a weight ratio of $8 \%, 5 \%$ and $1 \%$ respectively, with the remainder being deionized water. The surface result after polishing is obtained with a material removed rate of $38(\mathrm{~nm} / \mathrm{min})$ along with an ultra-smooth surface produced with $\mathrm{Ra}=0.41 \mathrm{~nm}$. With the help of X-ray photoelectron spectroscopy (XPS) method before and after polishing by CMS, the reaction mechanisms were elucidated. Analytical results show that $\mathrm{Y}_{3} \mathrm{Al}_{5} \mathrm{O}_{12}$ material produces $\mathrm{YOOH}$ and $\mathrm{AlOOH}$ in $\mathrm{Na}_{2} \mathrm{SiO}_{3}$ solution, then combines with $-\mathrm{Si}-\mathrm{OH}$ to form ( $\mathrm{Y}-\mathrm{Si}$ ) and (Al-Si) with significantly reduced hardness compared to other $\mathrm{Y}_{3} \mathrm{Al}_{5} \mathrm{O}_{12}$ materials, these products combine with $\mathrm{MgO}$ to form montmorillonites $\left(3 \mathrm{MgO}-\mathrm{Al}_{2} \mathrm{O}_{3}-3 \mathrm{SiO}_{2}-3 \mathrm{Y}_{2} \mathrm{O}_{3}-5 \mathrm{Al}_{2} \mathrm{O}_{3}\right)$. With this formation, the surface layer of $\mathrm{Y}_{3} \mathrm{Al}_{5} \mathrm{O}_{12}$ material becomes soft and is easily removed by $\mathrm{ZrO}_{2}$ abrasive particles under the influence of mechanical polishing, resulting in superfine surfaces are generated from the proposed CMS model.

\section{Introduction}

Nowadays, optical and laser devices are constantly evolving [1-3], the demand for the fabrication of functional materials in this field is increasing, in which $\mathrm{Y}_{3} \mathrm{Al}_{5} \mathrm{O}_{12}$ material has outstanding properties such as good optical properties, high thermal conductivity along with combinations of excellent rare earth ionic [4-6]. However, with difficult-to-machine properties such as high brittleness and hardness, it is difficult to achieve ultra-precise surface quality, with low surface quality that will reduce the efficiency of the laser, due to the low-quality surface will cause local energy accumulation for laser scattering [7-9]. In addition, the cost of the $\mathrm{Y}_{3} \mathrm{Al}_{5} \mathrm{O}_{12}$ material processing process also increases significantly due to its chemically stable nature thereby making the residual material removal rate low.

In recent years various ultra-precision machining methods have been used to produce ultra-fine $\mathrm{Y}_{3} \mathrm{Al}_{5} \mathrm{O}_{12}$ workpiece surfaces. The main methods used include chemical, magnetorheological finishing, mechanical, and chemical mechanical slurry (CMS) polishing $[10,11]$. When mechanical and magnetorheological polishing for $\mathrm{Y}_{3} \mathrm{Al}_{5} \mathrm{O}_{12}$ material, it is necessary to use abrasive particles with a higher hardness than $\mathrm{Y}_{3} \mathrm{Al}_{5} \mathrm{O}_{12}$, in this case, scratches appear along with which the $\mathrm{Y}_{3} \mathrm{Al}_{5} \mathrm{O}_{12}$ workpiece surfaces are easily displaced and appear large protrusions after polishing $[12,13]$. Meanwhile, chemical polishing processes with $\mathrm{Y}_{3} \mathrm{Al}_{5} \mathrm{O}_{12}$ material by phosphoric acid at high temperature and concentration will adversely affect the environment and equipment, in addition, create corrosion pits on the surface after polishing along with the ability to remove residuals on the surface of uneven workpieces [14]. These characteristics suggest that mechanical or chemical polishing alone is not suitable for polishing $\mathrm{Y}_{3} \mathrm{Al}_{5} \mathrm{O}_{12}$ 
material. Studies by Wang et al. [15] show that when combined mechanical and chemical action in polishing processes can produce high surface quality by soft abrasive particles. In the process of polishing by CMS, the composition of the CMS has a great influence on the cost and surface quality, the current studies mainly focus on polishing $\mathrm{Y}_{3} \mathrm{Al}_{5} \mathrm{O}_{12}$ material by colloidal silica. $\mathrm{Y}_{3} \mathrm{Al}_{5} \mathrm{O}_{12}$ material surfaces can be made in nanometer form when polished by chemical cloth and colloidal silica. The studies by $\mathrm{Li}$ et al. [16] showed that the surface of $\mathrm{Y}_{3} \mathrm{Al}_{5} \mathrm{O}_{12}$ material was significantly improved when polishing by CMS containing a mixture of $\mathrm{SiO}_{2}$ and $\mathrm{NaOH}$ suspensions, but the removal capacity of the workpiece residue was low $0.29(\mathrm{~nm} / \mathrm{min})$. Besides, another factor affecting the use of colloidal silica is that the ability to remove the processing residue is reduced in the process of reusing colloidal silica to produce - $\mathrm{Si}-\mathrm{OH}$ [17-19]. Several studies have been conducted to improve the performance of colloidal silica, however, the performance improvement is still limited [20]. As such, there are still many problems to be solved in CMS polishing for $\mathrm{Y}_{3} \mathrm{Al}_{5} \mathrm{O}_{12}$, which necessitates the creation of a new CMS blend for efficient material removal and improved surface quality better.

The polishing process uses a mixture of colloidal silica, mechanical polishing processes and chemical reactions are grouped together because the $-\mathrm{Si}-\mathrm{OH}$ produced are distributed on the surface of the silica particles as a reactant. With this feature, the polishing process performance is degraded because there is unbalance between chemical and mechanical polishing effects, therefore need to generate the $\mathrm{Si}-\mathrm{OH}$ group in ionic form instead of solid form on abrasive particles. This process is solved by $\mathrm{Na}_{2} \mathrm{SiO}_{3}$ solution, in which $\mathrm{Si}-\mathrm{OH}$ groups are generated by hydrolysis of $\mathrm{SiO}_{3}{ }^{2-}$ [21]. In this work, the $-\mathrm{Si}-\mathrm{OH}$ components are separated from the abrasive particles created by the $\mathrm{Na}_{2} \mathrm{SiO}_{3}-5 \mathrm{H}_{2} \mathrm{O}$ solution along with the mechanical process performed by the $\mathrm{ZrO}_{2}$ abrasive. Besides that, the polishing processes by $\mathrm{CMS}$ are added with $\mathrm{MgO}$ to improve the ability to material remove as well as further improve the surface quality. Experimental processes have been performed showing that $\mathrm{CMS}$ containing percentage composition of $\mathrm{Na}_{2} \mathrm{SiO}_{3}-5 \mathrm{H}_{2} \mathrm{O}, \mathrm{ZrO}_{2}$, and $\mathrm{MgO}$ of $5 \%, 8 \%$, and $1 \%$, respectively, gives the highest polishing efficiency of $\mathrm{Y}_{3} \mathrm{Al}_{5} \mathrm{O}_{12}$ material.

\section{Experimental Description}

The $\mathrm{Y}_{3} \mathrm{Al}_{5} \mathrm{O}_{12}$ workpieces used in $\mathrm{CMS}$ polishing are diameter and high of $16 \mathrm{~mm}$ and $6 \mathrm{~mm}$. The materials used for $\mathrm{CMS}$ polishing include deionized water, $\mathrm{Na}_{2} \mathrm{SiO}_{3}-5 \mathrm{H}_{2} \mathrm{O}$ with a purity of $99.9 \%$, $\mathrm{MgO}$ and $\mathrm{ZrO}_{2}$ with average particle size $50 \mathrm{~nm}$. Commercial colloidal silica containing $10 \%$ by weight $\mathrm{SiO}_{2}$ was used as a control in CMS. Experimental procedures were performed on a LAM-PLAN polishing machine as shown in Fig. 1. The machining parameters of the grinding and polishing processes are described in Table 1. 
Table 1

Setting parameters for grinding and polishing of $\mathrm{Y}_{3} \mathrm{Al}_{5} \mathrm{O}_{12}$ material

\begin{tabular}{|llllll|}
\hline Number & Characteristic & Force & CMS flow rate (ml/min) & Speed (rpm) & Pad \\
\hline 1 & & $(\mathrm{~N})$ & & & \\
\hline 2 & Grinding & 25 & 12 & 50 & 673 LAA10-3M \\
\hline
\end{tabular}

In order to find the most effective CMS polishing compound for $\mathrm{Y}_{3} \mathrm{Al}_{5} \mathrm{O}_{12}$ material, different slurries were investigated with the ingredients listed in Table 2. In case it is necessary to increase the amount of $-\mathrm{OH}$, the mixtures are added with an appropriate amount of $\mathrm{NaOH}$ to give the required $\mathrm{pH}$.

The surface morphology of $\mathrm{Y}_{3} \mathrm{Al}_{5} \mathrm{O}_{12}$ material after polishing by different CMS mixtures for 120 min was observed by an MX-40 optical microscope. The surface quality and depth of scratches were measured on a Zygo NewView 7100 roughness test, the amount of material removed was determined by the scraping method.

Table 2

Setting different CMS polishing mixes

\begin{tabular}{|llllll|}
\hline $\mathrm{CMS}$ & $\mathrm{pH}$ & $\mathrm{MgO}(\%)$ & $\mathrm{ZrO}_{2}(\%)$ & $\mathrm{Na}_{2} \mathrm{SiO}_{3}-5 \mathrm{H}_{2} \mathrm{O}(\%)$ & Solvent \\
\hline CMS-1 & - & 0 & 8 & 0 & Alcohol \\
\hline CMS-2 & 3 & 0 & 8 & 0 & Deionized water \\
CMS-3 & 13 & 0 & 8 & 0 & Deionized water \\
CMS-4 & 13 & 0 & 8 & 5 & Deionized water \\
CMS-5 & 13 & 1 & 8 & 5 & Deionized water \\
\hline
\end{tabular}

\section{Results And Discussion}

\subsection{Polished performance by different CMS}

The $\mathrm{Y}_{3} \mathrm{Al}_{5} \mathrm{O}_{12}$ material was polished with the same treatment parameters by colloidal silica and the new CMS to investigate the performance of polishing slurries. The results of surface roughness and material removal are as described in Figs. 2 and 3 . Surface quality results are obtained with $\mathrm{Ra}=1.637 \mathrm{~nm}$ when polishing with silica while surface roughness with CMS is suggested for surface quality with Ra $=0.471$ $\mathrm{nm}$, thus quality surface has improved $71 \%$. The material removal capacity when using colloidal silica is $8(\mathrm{~nm} / \mathrm{min})$ while with the proposed CMS it is $31(\mathrm{~nm} / \mathrm{min})$, thus with the proposed method for superior machining material removal (increase $287 \%$ ) compared with silica slurry. The results show excellent polishing ability from CMS proposed for polishing $\mathrm{Y}_{3} \mathrm{Al}_{5} \mathrm{O}_{12}$ materials. 


\subsection{Mechanism of the surface reactive layer to different CMS}

With CMS slurries used in the polishing process of $\mathrm{Y}_{3} \mathrm{Al}_{5} \mathrm{O}_{12}$ materials as described in Table 2, the results show the ability to remove materials as described in Fig. 4. The results show that when the solvent used in CMS-1 is alcohol, the ability to remove the layer of material is negligible. It can be seen that the $\mathrm{Y}_{3} \mathrm{Al}_{5} \mathrm{O}_{12}$ material has a higher hardness (with Moh 8.5) than the $\mathrm{ZrO}_{2}$ abrasive particle (with Moh 7.5), so the mechanical polishing process is not effective. With the CMS-2 polishing compound, using deionized water as the solvent instead of alcohol showed a significantly increased ability to remove materials. In the solvent medium is deionized water, the reaction with $\mathrm{Y}_{3} \mathrm{Al}_{5} \mathrm{O}_{12}$ creates a hydrated layer on the surface of the $\mathrm{Y}_{3} \mathrm{Al}_{5} \mathrm{O}_{12}$ workpiece, $\mathrm{ZrO}_{2}$ abrasive particles have a higher hardness than this layer, thus this layer is easily removed by abrasive particles. When adding the chemicals $\mathrm{NaOH}, \mathrm{Na}_{2} \mathrm{SiO}_{3}-5 \mathrm{H}_{2} \mathrm{O}, \mathrm{MgO}$ to the deionized water, the material removal increased significantly. Thus, under the influence of these chemicals, beneficial reactions have been created for the material removed process. The surface morphology of $\mathrm{Y}_{3} \mathrm{Al}_{5} \mathrm{O}_{12}$ material is shown in Fig. 5 with different CMS after 120 minutes of polishing, the results show that the surface quality and the ability to material removed are better improved when respectively adding components $\mathrm{NaOH}, \mathrm{Na}_{2} \mathrm{SiO}_{3}-5 \mathrm{H}_{2} \mathrm{O}, \mathrm{MgO}$ into deionized water. Thus, with the polishing method by CMS, the components of deionized water, $\mathrm{NaOH}, \mathrm{Na}_{2} \mathrm{SiO}_{3}-5 \mathrm{H}_{2} \mathrm{O}, \mathrm{MgO}$ have a very important role in the removal rate of materials and the surface quality of YAG materials.

\subsection{Hydration reaction}

Many researchers have studied the interaction between the polishing mixture and the workpiece surface $[22,23]$. In this study, the hydration reaction mechanisms on the workpiece surface were investigated. The generation of $\mathrm{AlOOH}$ and $\mathrm{YOOH}$ components is a result of the formation of $\mathrm{Al}-\mathrm{OH}$ and $\mathrm{Y}-\mathrm{OH}$ on the $\mathrm{Y}_{3} \mathrm{Al}_{5} \mathrm{O}_{12}$ crystal surface. As depicted in Fig. 6, due to the breakage of the $\mathrm{Al}-\mathrm{O}$ and $\mathrm{Y}-\mathrm{O}$ bond, a lot of voids are created for the $O$ atom and unsaturated metal atoms are formed on the surface of the $\mathrm{Y}_{3} \mathrm{Al}_{5} \mathrm{O}_{12}$ workpiece. Unsaturated metal atoms tend to adsorb $\mathrm{H}_{2} \mathrm{O}$ by forming $\mathrm{Al}-\mathrm{O}$ bonds and $\mathrm{Y}-\mathrm{O}$ bonds. Meanwhile, $\mathrm{H}_{2} \mathrm{O}$ dissociates into the $\mathrm{H}$ atom and $-\mathrm{OH}$ group. At this time, the $\mathrm{O}$ atoms will bond with neighboring $\mathrm{H}$ atoms on the $\mathrm{Y}_{3} \mathrm{Al}_{5} \mathrm{O}_{12}$ surface and form the $-\mathrm{OH}$ group. Thus, two types of hydroxide groups in $\mathrm{CMS}$ and on $\mathrm{Y}_{3} \mathrm{Al}_{5} \mathrm{O}_{12}$ surface bond together, forming $\mathrm{AlOOH}$ and $\mathrm{YOOH}$. Besides, $\mathrm{H}_{2} \mathrm{O}$ tends to dissociate into the $-\mathrm{OH}$ group in an alkaline environment, promoting hydration reaction [24]. With this mechanism, CMS-3 has better polishing performance than CMS-2.

\subsection{The role of $\mathrm{Na}_{2} \mathrm{SiO}_{3}-5 \mathrm{H}_{2} \mathrm{O}$ in the polishing process with}

CMS

The XPS spectral descriptions as shown in Fig. 7 combine with the binding energy reference parameters listed in Table $3[25,26]$ show that different elements exist on the $\mathrm{Y}_{3} \mathrm{Al}_{5} \mathrm{O}_{12}$ workpiece surface before and after polishing by CMS-4. The analysis results of XPS spectra show that the changes of binding energies 
corresponding to $\mathrm{Al}_{2} \mathrm{SiO}_{5}$ and $\mathrm{Y}_{2} \mathrm{SiO}_{5}$ are generated on the surface of the $\mathrm{Y}_{3} \mathrm{Al}_{5} \mathrm{O}_{12}$ workpiece during the polishing process. Figs. 7a and $7 \mathrm{~b}$ depict the analysis of Si $2 p$ and $\mathrm{O} 1 \mathrm{~s}$ spectra after polishing of the surface layer with extreme points Si2p (102.51 and $101.40 \mathrm{eV}$ ) and $01 \mathrm{~s}(531.3$ and $53.80 \mathrm{eV})$, respectively, this process shows that the products generated on the surface of the post-polished workpiece are $\mathrm{Al}_{2} \mathrm{SiO}_{5}$ and $\mathrm{Y}_{2} \mathrm{SiO}_{5}$, respectively. Figs. 7c and $\mathrm{d}$ results of the peak analysis of $\mathrm{Y} 3 \mathrm{~d}$ (158.01 and $160.05 \mathrm{eV}$ ) and $\mathrm{Al} 2 \mathrm{p}\left(74.27 \mathrm{eV}\right.$ ) also correspond to the formation of $\mathrm{Al}_{2} \mathrm{SiO}_{5}$ and $\mathrm{Y}_{2} \mathrm{SiO}_{5}$.

With the presence of these materials on the $\mathrm{Y}_{3} \mathrm{Al}_{5} \mathrm{O}_{12}$ workpiece surface layer, the material removal process is easier because the $\mathrm{ZrO}_{2}$ abrasive particles have a higher hardness than the hardness of $\mathrm{Al}_{2} \mathrm{SiO}_{5}$ and $\mathrm{Y}_{2} \mathrm{SiO}_{5}$. The dehydration mechanisms are as depicted in Fig. 8, in which the $\mathrm{Y}_{3} \mathrm{Al}_{5} \mathrm{O}_{12}$ workpiece surface will react with the $\mathrm{Si}-\mathrm{OH}$ group created by the $\mathrm{SiO}_{3}{ }^{2-}$ reduction reaction. $\mathrm{The} \mathrm{Y}-\mathrm{OH}$ and $\mathrm{Al}-\mathrm{OH}$ groups present on the surface layer of the workpiece tend to combine with the $\mathrm{Si}-\mathrm{OH}$ group to form $\mathrm{Y}-\mathrm{O}-\mathrm{Si}$ and $\mathrm{Al}-\mathrm{O}-\mathrm{Si}$ bonds in deionized water. The hydration reaction mechanisms are described as follows:

$2 \mathrm{YOOH}+\mathrm{SiO}_{3}{ }^{2-} \rightarrow \mathrm{Y}_{2} \mathrm{SiO}_{5}+2 \mathrm{OH}^{-}$

$2 \mathrm{AlOOH}+\mathrm{SiO}_{3}{ }^{2-} \rightarrow \mathrm{Al}_{2} \mathrm{SiO}_{5}+2 \mathrm{OH}^{-}$

Table 3

Elemental binding energies

\begin{tabular}{|c|c|c|c|c|c|}
\hline Chemical composition & Al $2 p(e V)$ & $\mathrm{Mg} 1 \mathrm{~s}(\mathrm{eV})$ & $01 \mathrm{~s}(\mathrm{eV})$ & Si 2p (eV) & Y 3d (eV) \\
\hline $\mathrm{Y}_{3} \mathrm{Al}_{5} \mathrm{O}_{12}$ & - & - & 530.47 & - & 157.43 \\
\hline $\mathrm{Al}_{2} \mathrm{SiO}_{5}$ & 74.27 & - & 531.30 & 102.51 & - \\
\hline \multirow[t]{2}{*}{$\mathrm{Y}_{2} \mathrm{SiO}_{5}$} & - & - & 530.80 & 101.40 & 158.00 \\
\hline & & & & & 160.05 \\
\hline $3 \mathrm{MgO}-\mathrm{Al}_{2} \mathrm{O}_{3}-3 \mathrm{SiO}_{2}-3 \mathrm{Y}_{2} \mathrm{O}_{3}-5 \mathrm{Al}_{2} \mathrm{O}_{3}$ & - & 1305.30 & - & 102.95 & - \\
\hline $\mathrm{MgO}$ & - & 1303.90 & - & - & - \\
\hline
\end{tabular}

After polishing by CMS-5, the results of XPS spectrum analysis with $\mathrm{Mg}$ 1s and Si 2p for the $\mathrm{Y}_{3} \mathrm{Al}_{5} \mathrm{O}_{12}$ workpiece are as described in Fig. 9. The result in Fig. 9a obtained the peak value of $\mathrm{Mg} 1 \mathrm{~s}(1305.3 \mathrm{eV})$ which corresponds to the montmorillonite $\left(3 \mathrm{MgO}-\mathrm{Al}_{2} \mathrm{O}_{3}-3 \mathrm{SiO}_{2}-3 \mathrm{Y}_{2} \mathrm{O}_{3}-5 \mathrm{Al}_{2} \mathrm{O}_{3}\right)$ formed on the surface of the $\mathrm{Y}_{3} \mathrm{Al}_{5} \mathrm{O}_{12}$ workpiece. Fig. 9b depicts XPS with Si 2p showing peaks at positions $102.51 \mathrm{eV}, 101.40 \mathrm{eV}$, and $102.95 \mathrm{eV}$, the results show that the formation of $\mathrm{Al}_{2} \mathrm{SiO}_{5}, \mathrm{Y}_{2} \mathrm{SiO}_{5}$, and $3 \mathrm{MgO}-\mathrm{Al}_{2} \mathrm{O}_{3}-3 \mathrm{SiO}_{2}-3 \mathrm{Y}_{2} \mathrm{O}_{3^{-}}$ $5 \mathrm{Al}_{2} \mathrm{O}_{3}$, respectively. 
The results of the above analyses show that the production of the montmorillonite product on the surface layer results from the reaction of $\mathrm{Y}_{3} \mathrm{Al}_{5} \mathrm{O}_{12}$ workpiece, $\mathrm{Na}_{2} \mathrm{SiO}_{3}$, and $\mathrm{MgO}$ ingots in deionized water. Previous studies have shown that the participation of $\mathrm{MgO}$ will accelerate the formation of silicate minerals into montmorillonite $\left(3 \mathrm{MgO}-\mathrm{Al}_{2} \mathrm{O}_{3}-3 \mathrm{SiO}_{2}-3 \mathrm{Y}_{2} \mathrm{O}_{3}-5 \mathrm{Al}_{2} \mathrm{O}_{3}\right)$ trilayers $[27,28]$. In which the secondary reaction between $\mathrm{Al}_{2} \mathrm{SiO}_{5}$ and $\mathrm{MgO}$ will form montmorillonite ( $3 \mathrm{MgO}-\mathrm{Al}_{2} \mathrm{O}_{3}-3 \mathrm{SiO}_{2}-3 \mathrm{Y}_{2} \mathrm{O}_{3}-5 \mathrm{Al}_{2} \mathrm{O}_{3}$ ) [29]. The resulting montmorillonite product is softer than $\mathrm{Al}_{2} \mathrm{SiO}_{5}$ and is therefore easily removed in mechanical polishing processes. This conversion benefits the CMS polishing process with improved surface quality as well as the ability to remove material residues.

\section{Conclusion}

Aim to create the super-smooth YAG workpiece surface, a new CMS polishing method was established with a mass percent composition including $\mathrm{ZrO}_{2}(8 \%), \mathrm{Na}_{2} \mathrm{SiO}_{3}-5 \mathrm{H}_{2} \mathrm{O}(5 \%), \mathrm{MgO}(1 \%)$, and deionized water. The results obtained after polishing by the proposed CMS- 5 give out an ultra-smooth surface with high material removal capacity. The products of surface layer reaction were determined through XPS analysis with the main conclusions being made as follows:

- The newly developed CMS-5 polishing compound has produced an ultra-smooth surface with $\mathrm{Ra}=$ $0.471 \mathrm{~nm}$ along with a high workpiece residue removal of $31(\mathrm{~nm} / \mathrm{min})$.

- The generated hydration reaction products including $\mathrm{AlOOH}$ and $\mathrm{YOOH}$ react with the Si-OH group present in the $\mathrm{Na}_{2} \mathrm{SiO}_{3}$ solution to form andalusite and yttrium silicate. These products will combine with $\mathrm{MgO}$ to form montmorillonite. Substances created on the surface have low hardness, therefore easily removed by mechanical polishing by $\mathrm{ZrO}_{2}$ abrasive particles. The result after this polishing process is an ultra-smooth surface with a high residual removal capacity.

- The generated hydration reaction products including $\mathrm{AlOOH}$ and $\mathrm{YOOH}$ reactive with the $\mathrm{Si}-\mathrm{OH}$ group present in the $\mathrm{CMS}$ polishing mixture to produce $\mathrm{Al}_{2} \mathrm{SiO}_{5}$ and $\mathrm{Y}_{2} \mathrm{SiO}_{5}$. These products will combine with $\mathrm{MgO}$ to form montmorillonite. Substances created on the surface have low hardness, therefore easily removed by mechanical polishing by $\mathrm{ZrO}_{2}$ abrasive particles. The result after this polishing process is an ultra-smooth surface with a high residual removal capacity. To create a new type of

polishing compound applicable to various workpieces based on the reaction of the Si-OH group with different materials. The newly created CMS blend is promising to apply to various difficult-tomachine materials: diamond, sapphire. With different materials, the percentage of components in CMS will be studied and optimized to give the best polishing performance.

\section{Declarations}

\section{ACKNOWLEDGMENT}

This work is financially supported by the Hanoi University of Industry. 
Conflict of Interest: The authors declare that they have no conflict of interest.

Ethical approval: This paper does not contain any studies with human participants or animals performed by any of the authors.

Consent to Participate: Consent to Participate was obtained from all individual participants included in the study.

Consent to Publish: Consent to Publish was obtained from all individual participants included in the study.

\section{Authors Contributions}

The authors confirm contribution to the paper as follows:

Author 1: Le Anh Duc

Conceived and designed the analysis; Collected the data; Analysis and interpretation of results; Performed the analysis; Wrote the paper.

Author 2: Pham Minh Hieu

Collected the data; Analysis and interpretation of results; Performed the analysis; Wrote the paper.

Author 3: Nguyen Minh Quang

Study conception and design; Collected the data; Analysis and interpretation of results; Wrote the paper.

All authors reviewed the results and approved the final version of the manuscript.

Availability of data and materials: This paper is not based on original data.

\section{References}

1. Peng Y, Shen B, Wang Z, Yang P, Yang W, Bi G (2021) Review on polishing technology of small-scale aspheric optics. The International Journal of Advanced Manufacturing Technology 115(4):965-987. doi:10.1007/s00170-021-07202-3

2. Martins FV, Mattos CT, Cordeiro WJB, Fonseca EM (2019) Evaluation of zirconia surface roughness after aluminum oxide airborne-particle abrasion and the erbium-YAG, neodymium-doped YAG, or CO2 lasers: A systematic review and meta-analysis. J Prosthet Dent 121(6):895-903e892. doi:https://doi.org/10.1016/j.prosdent.2018.07.001

3. Guo W, Hua M, Tse PW-T, Mok ACK (2012) Process parameters selection for laser polishing DF2 (AISI 01) by Nd:YAG pulsed laser using orthogonal design. The International Journal of Advanced Manufacturing Technology 59(9):1009-1023. doi:10.1007/s00170-011-3558-1 
4. Zhang Y, Bu A, Xiang Y, Yang Y, Wei X, Chen W, Cheng H, Wang L, Li M, Lu L (2021) Rapid synthesis of Y3Al5012 powders via plasma electrolysis. Ceram Int 47(21):30147-30155.

doi:https://doi.org/10.1016/j.ceramint.2021.07.193

5. Li J, Ma Z, Wang F, Wang Z (2021) Synthesis and mechanoluminescent properties of submicro-sized Y3Al5012:Ce3+ particles. Chem Phys Lett 775:138664.

doi:https://doi.org/10.1016/j.cplett.2021.138664

6. Hsiao W-T, Tseng S-F, Huang K-C, Wang Y-H, Chen M-F (2011) Pulsed Nd:YAG laser treatment of monocrystalline silicon substrate. The International Journal of Advanced Manufacturing Technology 56(1):223-231. doi:10.1007/s00170-011-3170-4

7. Zhang Z, Jin Z, Guo J, Han X, Mu Q, Zhu X (2019) A novel chemical mechanical polishing slurry for yttrium aluminum garnet crystal. Appl Surf Sci 496:143601. doi:10.1016/j.apsusc.2019.143601

8. Li J, Luo R, Li Q, Wang T (2008) Study of the infiltration and mechanical behavior of C/C composites prepared by ECVI. Materials Science and Engineering: A 480(1-2):278-282.

doi:10.1016/j.msea.2007.07.016

9. Chen J, Lu X, Wen Q, Jiang F, Lu J, Lei D, Pan Y (2021) Review on laser-induced etching processing technology for transparent hard and brittle materials. The International Journal of Advanced Manufacturing Technology 117(9):2545-2564. doi:10.1007/s00170-021-07853-2

10. Wei X, Yang X, Xie X, Hu W (2016) A material removal rate model-based chemical action of ultra-thin SUS304 substrate in chemical mechanical polishing. The International Journal of Advanced Manufacturing Technology 85(1):287-290. doi:10.1007/s00170-015-7938-9

11. Liu D, Chen G, Hu Q (2017) Material removal model of chemical mechanical polishing for fused silica using soft nanoparticles. The International Journal of Advanced Manufacturing Technology 88(9):3515-3525. doi:10.1007/s00170-016-9069-3

12. Ross D, Yamaguchi H (2018) Nanometer-scale characteristics of polycrystalline YAG ceramic polishing. CIRP Ann 67(1):349-352. doi:https://doi.org/10.1016/j.cirp.2018.04.090

13. Mu Q, Jin Z, Han X, Yan Y, Zhang Z, Zhou P (2021) Effects of slurry pH on chemical and mechanical actions during chemical mechanical polishing of YAG. Appl Surf Sci 563:150359. doi:https://doi.org/10.1016/j.apsusc.2021.150359

14. Zhang Z, Jin Z, Guo J (2020) The effect of the interface reaction mode on chemical mechanical polishing. CIRP J Manufact Sci Technol 31:539-547. doi:10.1016/j.cirpj.2020.08.005

15. Wang K, Li W, Qu Q, Wang Z (2020) Chemical mechanical polishing of the narrow channel of a channel-cut crystal. The International Journal of Advanced Manufacturing Technology 108(5):16911700. doi:10.1007/s00170-020-05443-2

16. Li J, Zhu Y, Chen C (2008) Chemical Mechanical Polishing of Transparent Nd:YAG Ceramics. Key Engineering Materials - KEY ENG MAT 375-376:278-282. doi:10.4028/www.scientific.net/KEM.375376.278

17. Suzuki H, Okada M, Namba Y, Goto $T$ (2019) Superfinishing of polycrystalline YAG ceramic by nanodiamond slurry. CIRP Ann 68(1):361-364. doi:https://doi.org/10.1016/j.cirp.2019.04.062 
18. Penta NK (2022) : 9 - Abrasive-free and ultra-low abrasive chemical mechanical polishing (CMP) processes. In: Babu, S. (ed.) Advances in Chemical Mechanical Planarization (CMP) (Second Edition). pp. 221-237. Woodhead Publishing,

19. Zhong Z-W (2020) Recent developments and applications of chemical mechanical polishing. The International Journal of Advanced Manufacturing Technology 109(5):1419-1430. doi:10.1007/s00170-020-05740-w

20. Liu T, Lei H (2017) Nd3+-doped colloidal SiO2 composite abrasives: Synthesis and the effects on chemical mechanical polishing (CMP) performances of sapphire wafers. Appl Surf Sci 413:16-26. doi:https://doi.org/10.1016/j.apsusc.2017.03.270

21. Goudarzi N, Chamjangali MA, Amin AH, Goodarzi M (2013) Effects of Surfactant and Polyelectrolyte on Distribution of Silicate Species in Alkaline Aqueous Tetraoctylammonium Silicate Solutions Using 29Si NMR Spectroscopy. Appl Magn Reson 44(9):1095-1103. doi:10.1007/s00723-013-0467-5

22. Dai S, Fu J, Lei H, Chen Y (2021) Study on the interaction between SiO2 and ZrO2 in the chemical mechanical polishing of zirconia ceramic with colloidal silica. Ceram Int 47(15):21642-21649. doi:https://doi.org/10.1016/j.ceramint.2021.04.177

23. Tweddle D, Hamer P, Shen Z, Moody MP, Wilshaw PR (2019) Identification of colloidal silica polishing induced contamination in silicon. Mater Charact 152:239-244.

doi:https://doi.org/10.1016/j.matchar.2019.04.029

24. Henderson MA (2002) The interaction of water with solid surfaces: fundamental aspects revisited. Surf Sci Rep 46(1):1-308. doi:https://doi.org/10.1016/S0167-5729(01)00020-6

25. Sakar N, Gergeroglu H, Akalin SA, Oguzlar S, Yildirim S (2020) Synthesis, structural and optical characterization of Nd: YAG powders via flame spray pyrolysis. Opt Mater 103:109819. doi:https://doi.org/10.1016/j.optmat.2020.109819

26. Ohuchi F, Ghose S, Engelhard M, Baer D (2006) Chemical bonding and electronic structures of the Al2SiO5 polymorphs, andalusite, sillimanite, and kyanite: X-ray photoelectron- and electron energy loss spectroscopy studies. American Mineralogist - AMER MINERAL 91:740-746. doi:10.2138/am.2006.1887

27. Harder H (2018) Clay mineral formation under lateritic weathering conditions. Clay Miner 12(4):281288. doi:10.1180/claymin.1977.012.4.01

28. Yin D, Niu X, Zhang K, Wang J, Cui Y (2018) Preparation of MgO doped colloidal SiO2 abrasive and their chemical mechanical polishing performance on c-, $r$ - and a-plane sapphire substrate. Ceram Int 44(12):14631-14637. doi:https://doi.org/10.1016/j.ceramint.2018.05.087

29. Cadars S, Guégan R, Garaga MN, Bourrat X, Le Forestier L, Fayon F, Huynh TV, Allier T, Nour Z, Massiot D (2012) New Insights into the Molecular Structures, Compositions, and Cation Distributions in Synthetic and Natural Montmorillonite Clays. Chem Mater 24(22):4376-4389. doi:10.1021/cm302549k

\section{Figures}




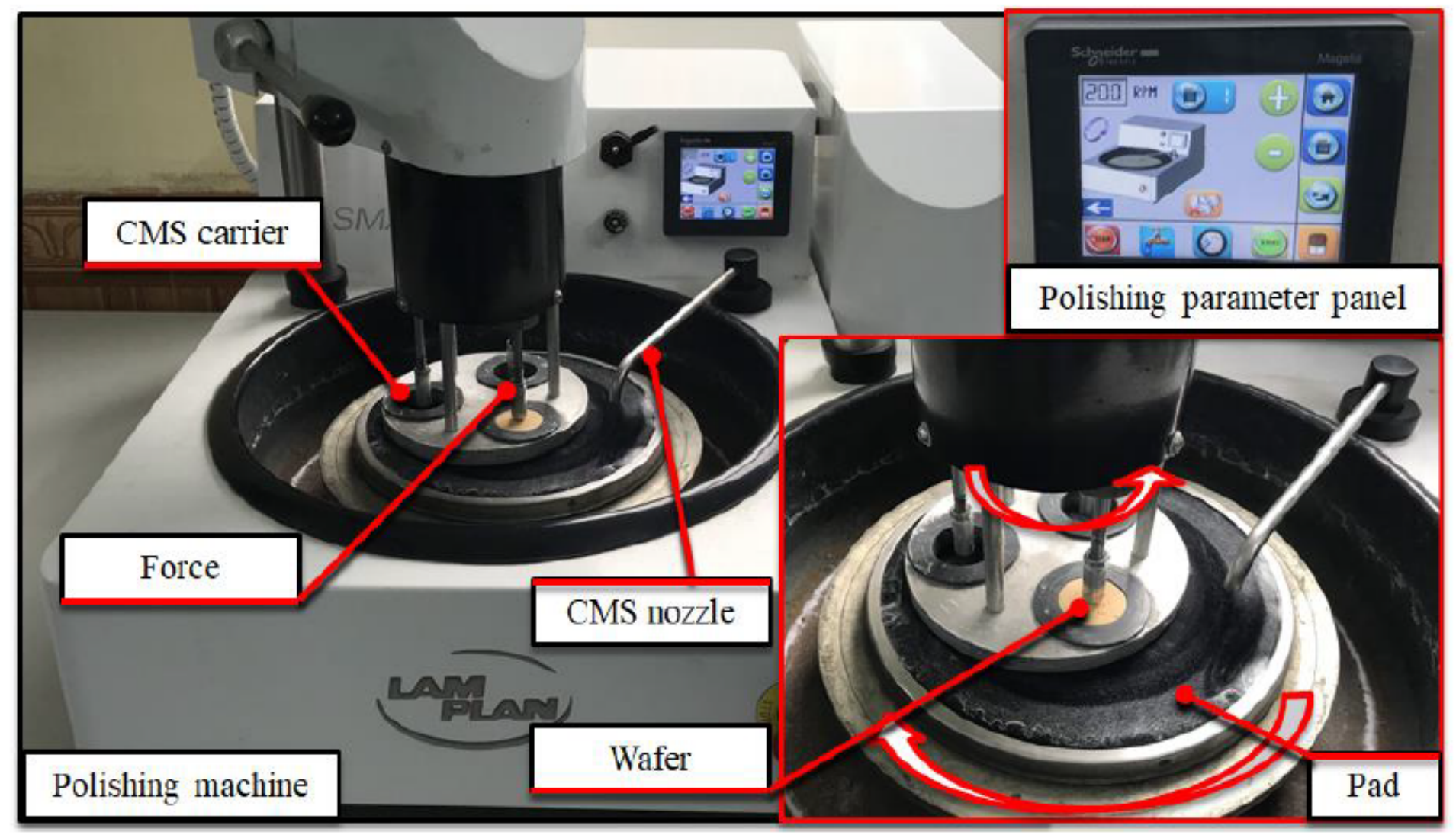

Figure 1

Image experiment equipment by CMS polishing 


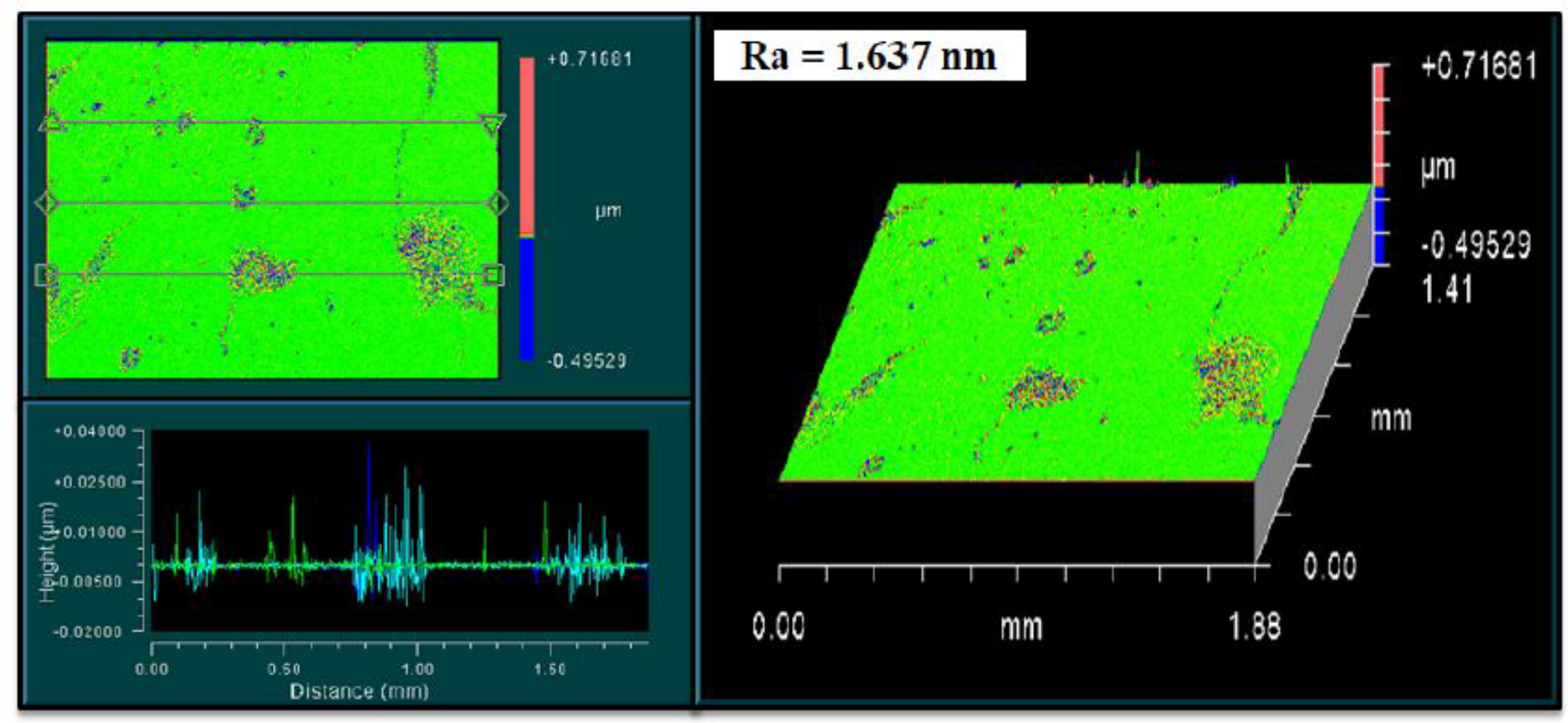

a) Colloidal Silica

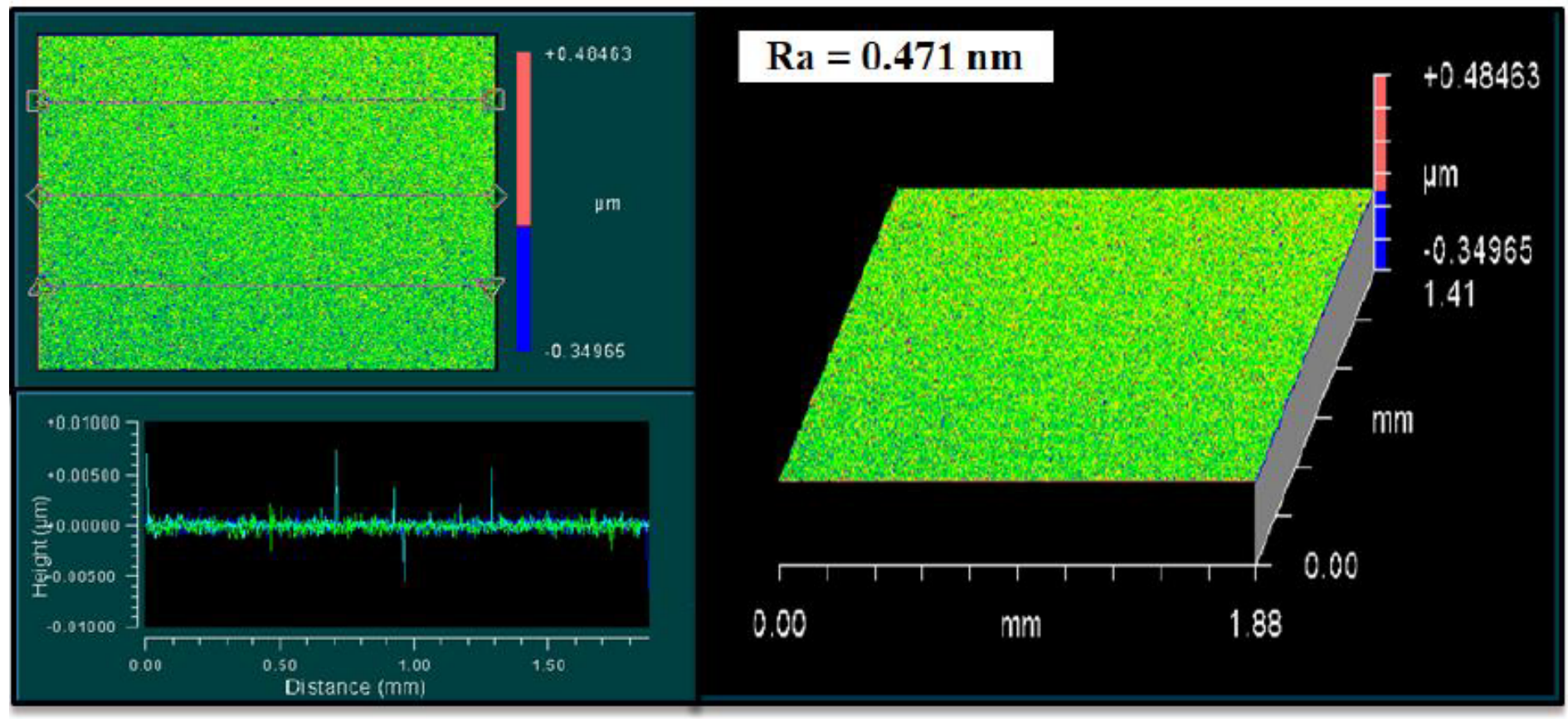

b) New CMS polishing

Figure 2

Surface morphology of $\mathrm{Y}_{3} \mathrm{Al}_{5} \mathrm{O}_{12}$ workpiece after polishing with different $\mathrm{CMS}$ 


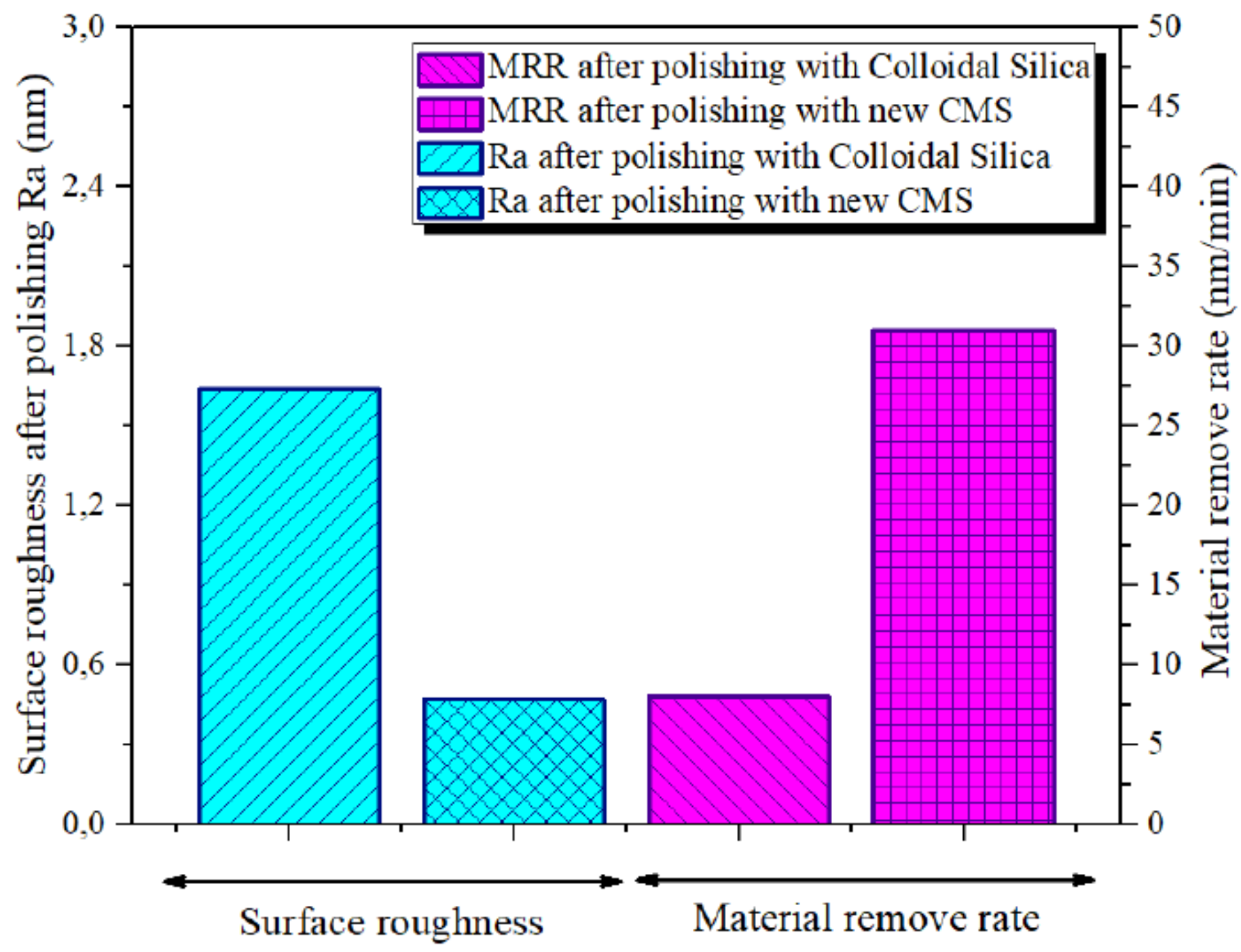

Figure 3

Surface quality and material removal rate with different CMS slurries 


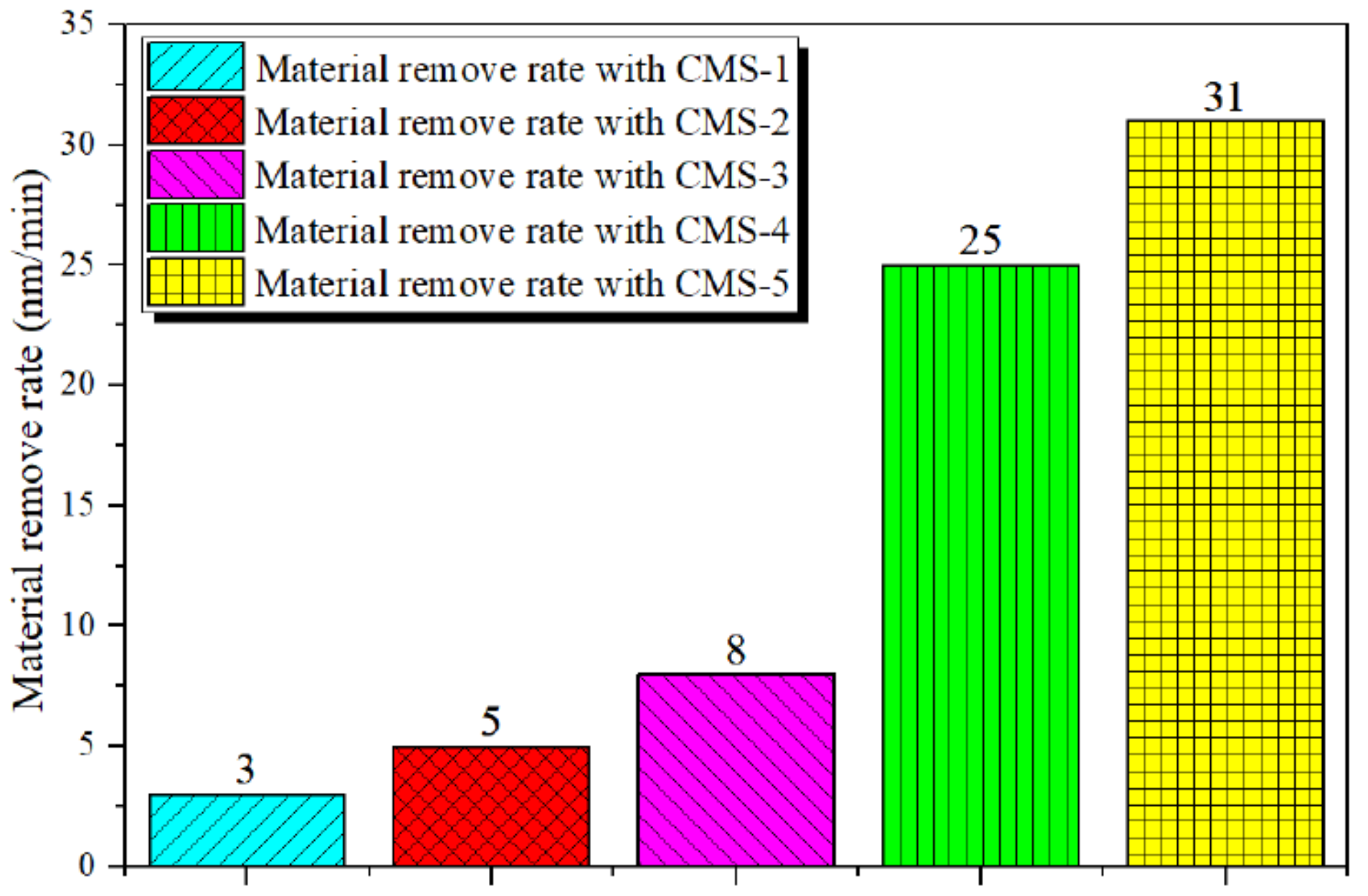

Figure 4

Material removal capabilities with different CMS 

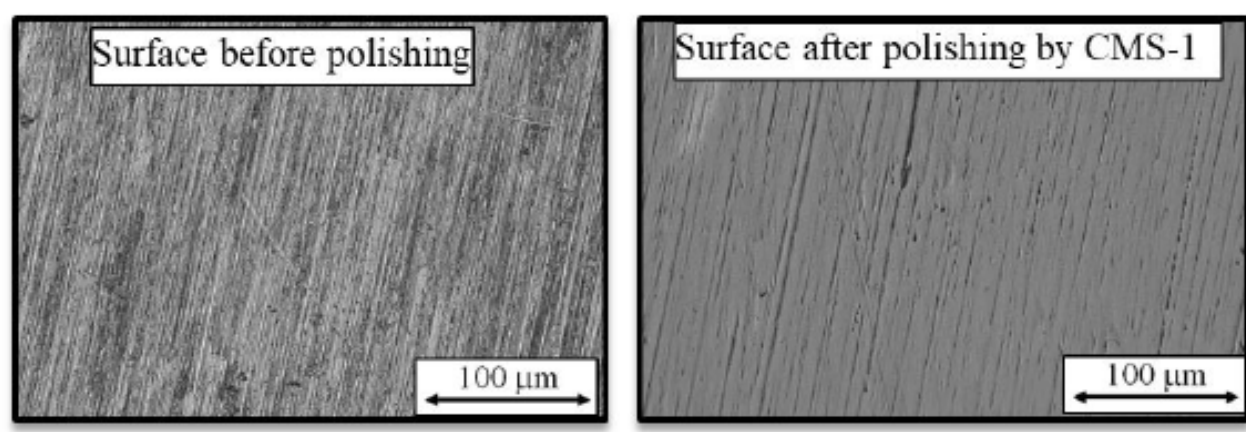

Surface after polishing by CMS-3
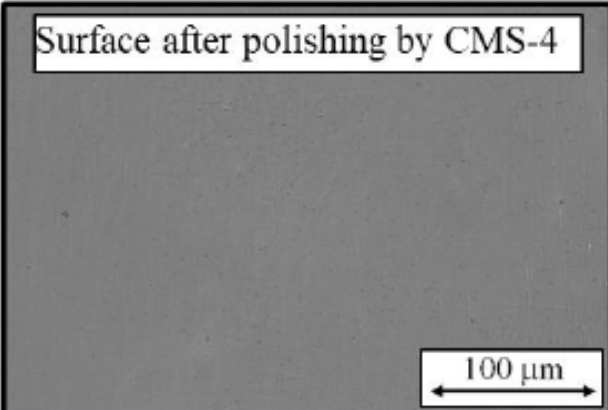

Surface after polishing by CMS-2

$100 \mu \mathrm{m}$

Surface after polishing by CMS-5

\section{Figure 5}

Surface morphology of YAG material after polishing by different CMS 


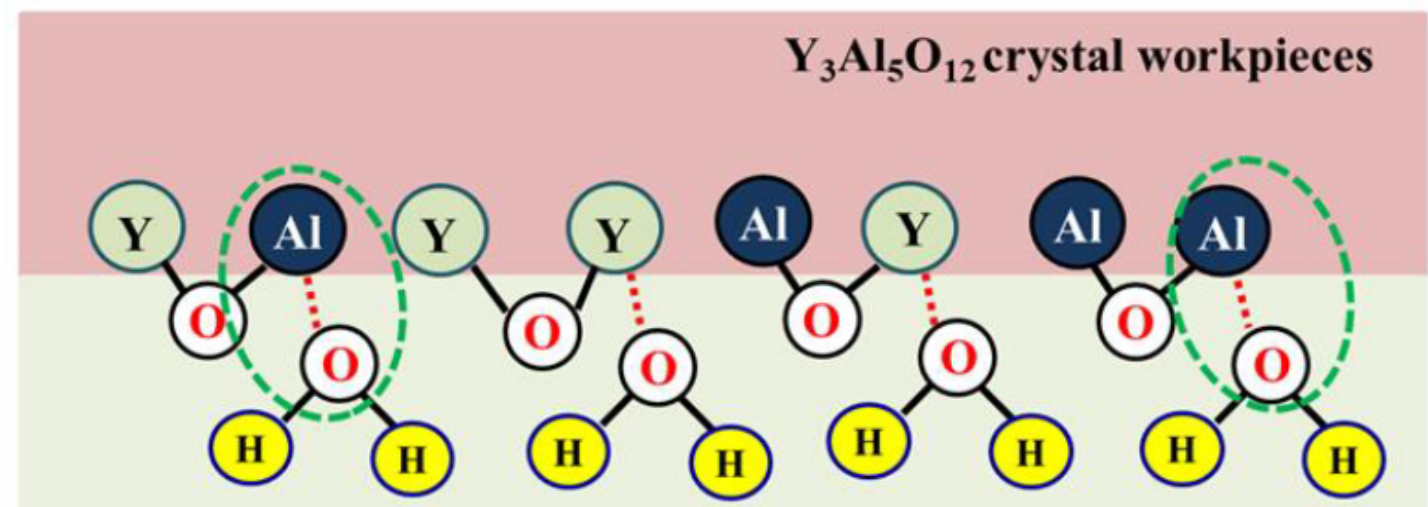

Absorption

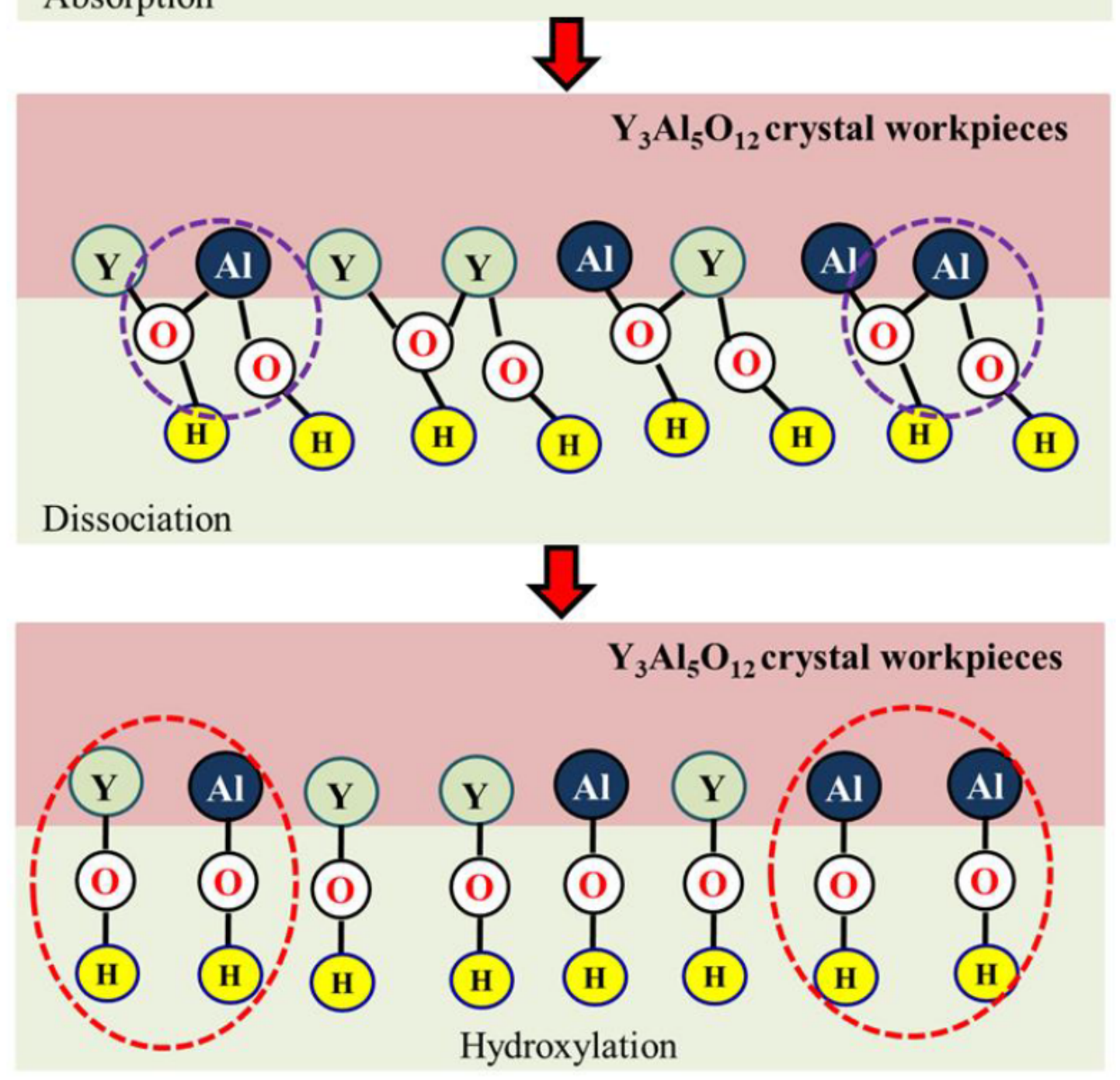

Figure 6

Hydration reaction on $\mathrm{Y}_{3} \mathrm{Al}_{5} \mathrm{O}_{12}$ workpiece surface 


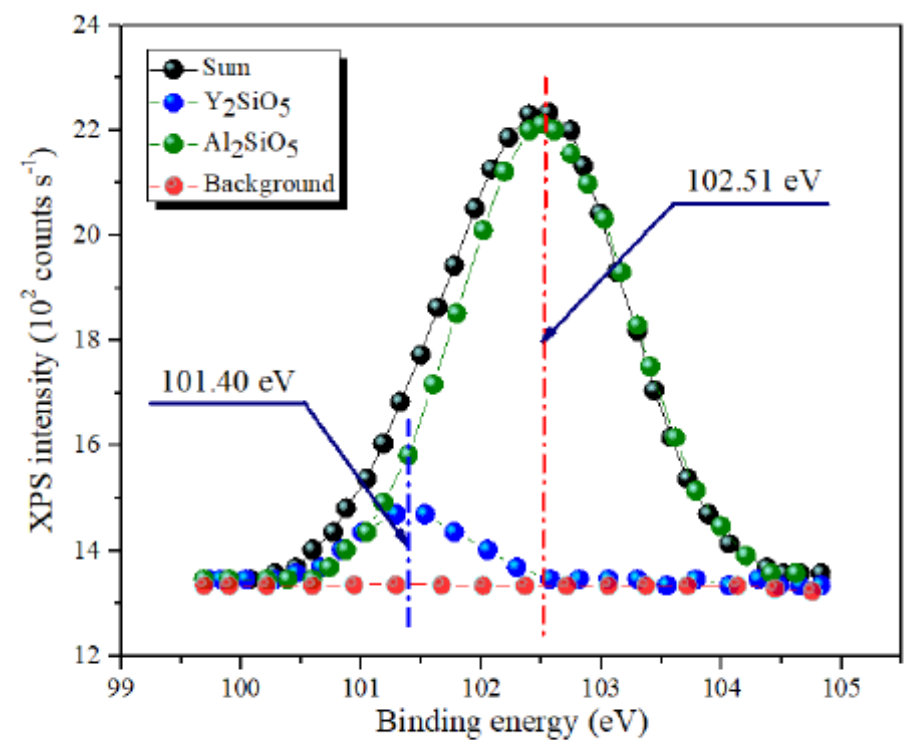

a) Si $2 p$ after polishing

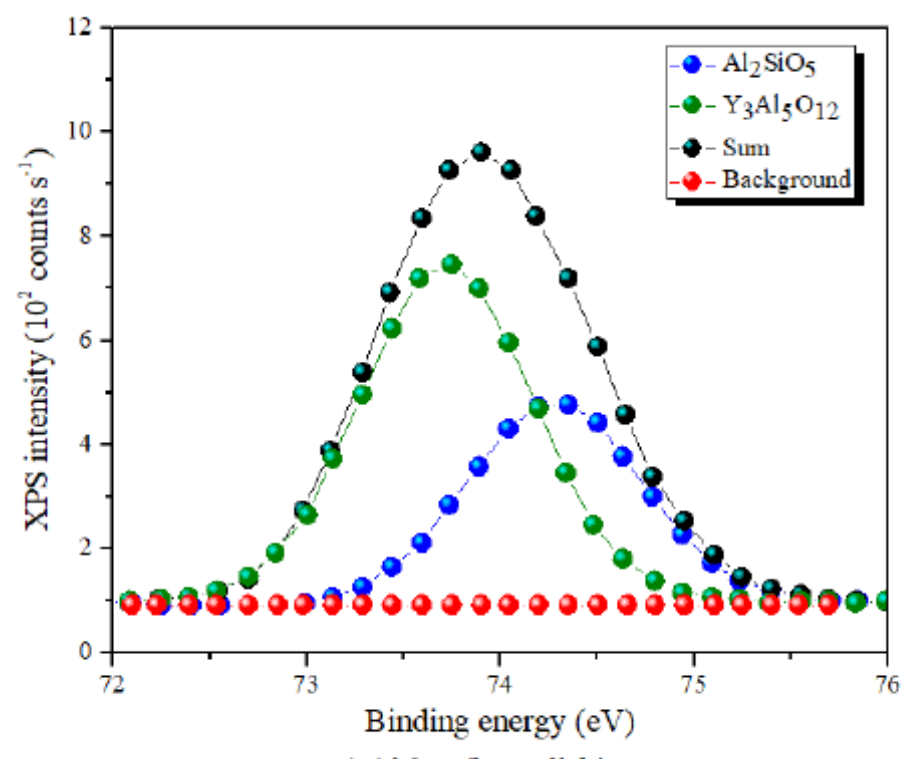

c) $\mathrm{Al} 2 \mathrm{p}$ after polishing

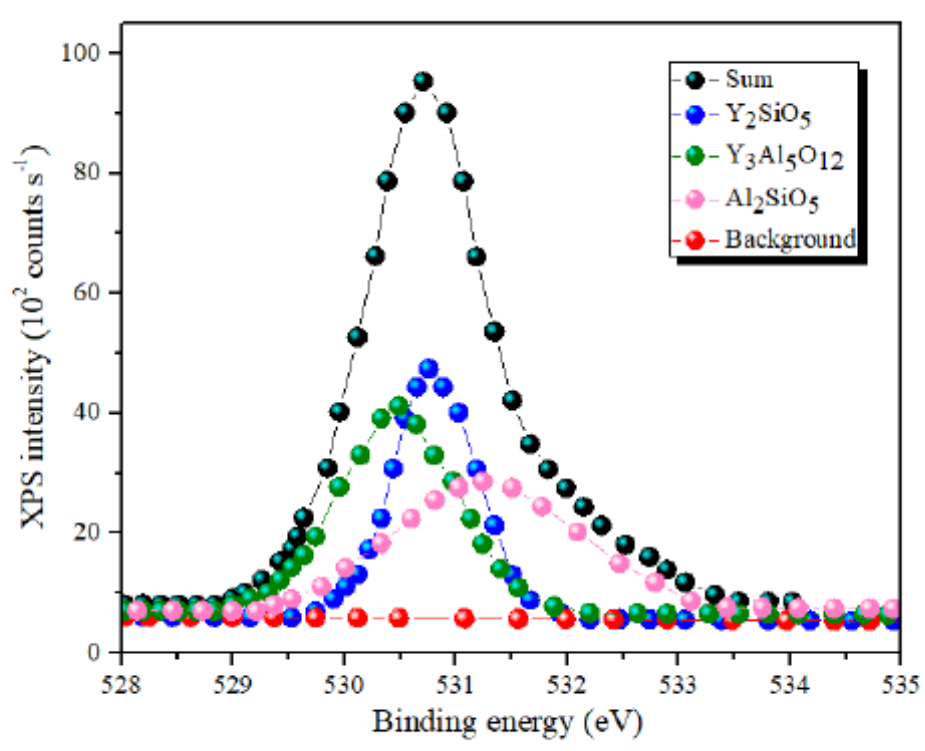

b) $\mathrm{O} 1 \mathrm{~s}$ after polishing

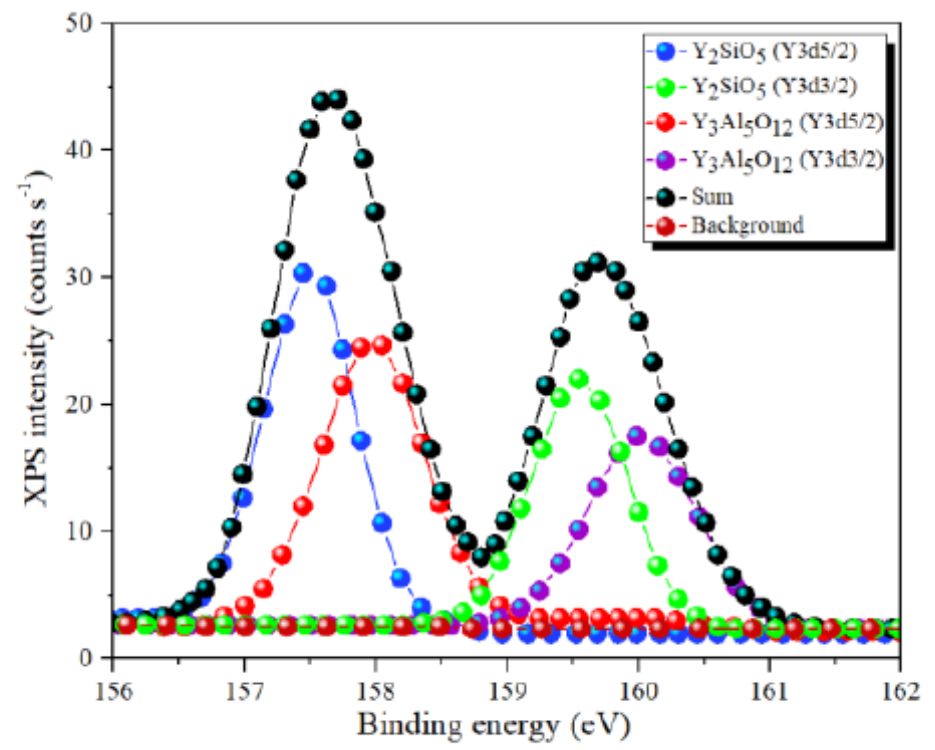

d) Y $3 p$ after polishing

Figure 7

Spectrum XPS after polishing 


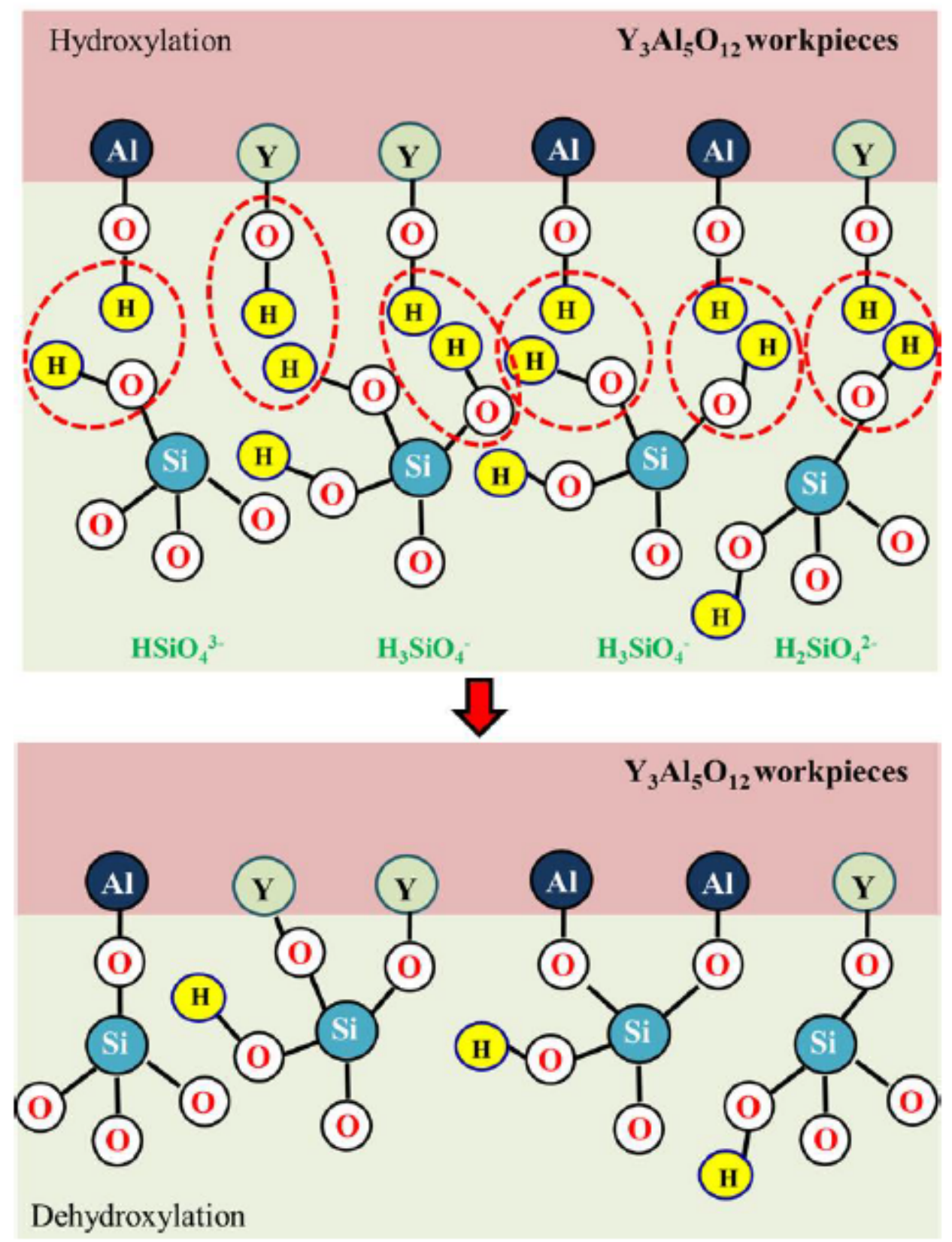

Figure 8

Diagram of dehydration reaction 


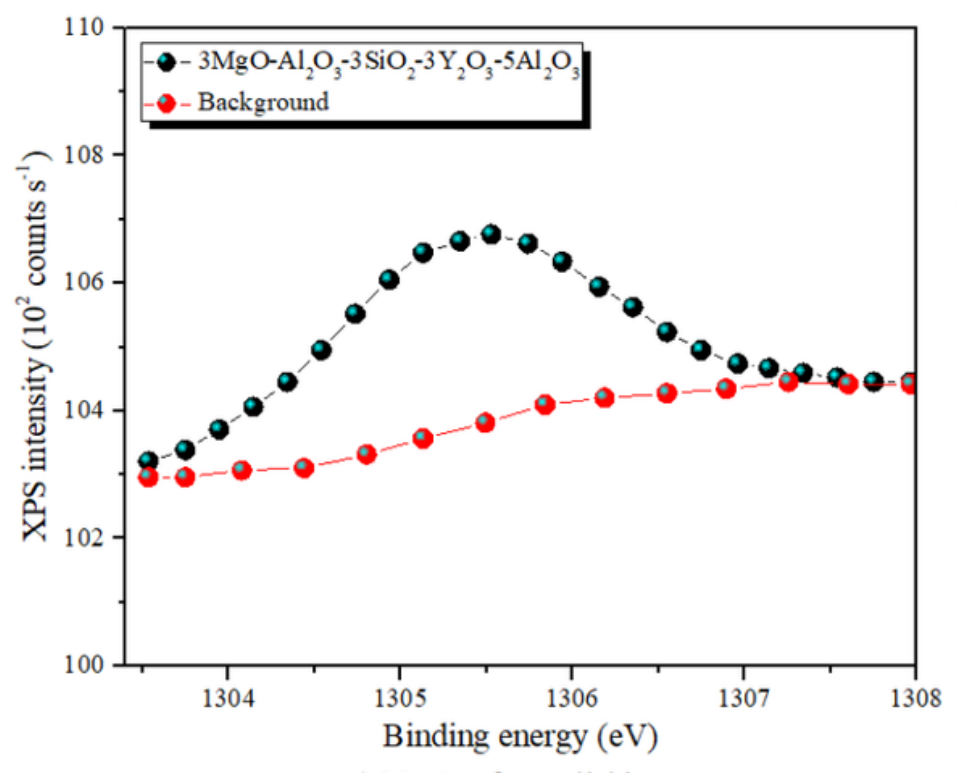

a) $\mathrm{Mg} 1 \mathrm{~s}$ after polishing

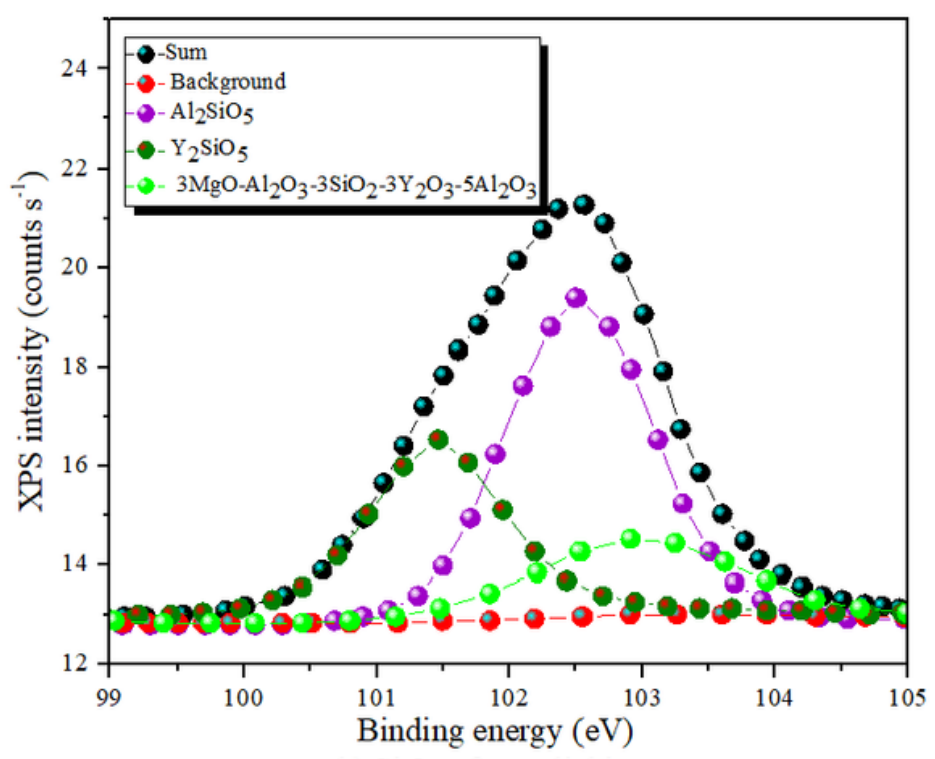

b) Si $2 p$ after polishing

Figure 9

Si $2 p$ and $M g$ 1s XPS spectra after polishing $\mathrm{Y}_{3} \mathrm{Al}_{5} \mathrm{O}_{12}$ workpiece by CMS-5 